\title{
304 鋼粗大柱状晶を用いた粒界腐食および粒界 割れの方位差依存性の研究
}

\author{
佐藤 昭規*.昆謙造*2 $\cdot$ 辻川 茂男 ${ }^{* 3} \cdot$ 久松 敬弘*3

\section{Effect of Misorientation on Intergranular Corrosion and Intergranular Stress Corrosion Cracking of Type 304 Steel with Coarse Columnar Crystals}

\author{
Akinori Sato, Kenzo Kon, Shigeo Tsujikawa, and Yoshihiro Hisamatsu
}

\begin{abstract}
Synopsis :
The effects of misorientation on intergranular corrosion in boiling $\mathrm{H}_{2} \mathrm{SO}_{4}-\mathrm{CuSO}_{4}$ and boiling $\mathrm{HNO}_{3}$ solutions and on intergranular stress corrosion cracking in $\mathrm{FeCl}_{3}$ solution were investigated on type 304 steel with coarse columnar crystals. As the deviations of the growing direction around $\langle 100\rangle$ orientation were within $10^{\circ}$, the grain boundaries were treated as simple tilt boundaries with $\langle 100\rangle$ rotation axis.

The depth of intergranular corrosion, $D_{\mathrm{I}}$, and the depth of intergranular stress corrosion cracking, $D_{\mathrm{C}}$, of the specimen water-quenched, followed by sensitization at $923 \mathrm{~K}$ for $7.2 \mathrm{ks}$ clearly decreased at coincidence boundaries $\left(\Sigma 13, \Sigma 17\right.$, and $\left.\sum 5\right)$ and the grain boundaries with rotation angle, $\omega$, which were less than $10^{\circ}$ and more than $40^{\circ} . D_{\mathrm{I}}$ and $D_{\mathrm{C}}$ of the specimen water-quenched, followed by sensitization at $823 \mathrm{~K}$ for $7.2 \mathrm{ks}$ after strained to $3.0 \%$ clearly decreased at coincidence boundaries and at the grain boundaries with $\omega$ which were more than $40^{\circ}$. However, $D_{\mathrm{I}}$ and $D_{\mathrm{C}}$ changed over a wide range at the grain boundaries with $\omega$ which were less than $10^{\circ}$. Schmid factor of component crystals was larger for deep $D_{\mathrm{I}}$ and $D_{\mathrm{C}}$, and was smaller for shallow $D_{\mathrm{I}}$ and $D_{\mathrm{C}}$. This suggests that $D_{1}$ and $D_{\mathrm{C}}$ do not only depend on $\omega$ but also on the degree of plastic deformation near grain boundaries.

According to observation of carbide precipitation at grain boundaries, carbides were recognized at random boundaries, but not recognized at coincidence boundaries and the grain boundaries with $\omega$ which were about $45^{\circ}$.
\end{abstract}

\section{1. 緒言}

結晶粒界に関連する諸現象は粒界構造に大きく低存す ることが知られており，特に䊉界破壊についてはその構 造之粒界偏析 ${ }^{122}$ 拈上び粘界すべり ${ }^{3 / 4)}$ との関係が検討 されている。また，料界腐食も重要で，粒界の方位差依 存性汇ついて多くの研究がある。たとえば，Boos と $\mathrm{Goux}^{5}$ は $\mathrm{Al}$ 双結晶の高温水中での粘界腐食について調 べ，粒界腐食深さに方位差依存性が西ることを，ARORA と METZGER ${ }^{6)}$ は $\mathrm{Al}$ 双絬晶の坋酸溶液中での粒界腐食 染さが対応粒界で減少することを，さらに FROMENT ${ }^{7)}$ も ステンレス双絬晶の硫酸溶液中で対応関係にある粒界で は腐食が起こりにくいことを報告している，著者ら ${ }^{8)}$ インュネル 600 の硫酸溶液中での精界腐食挙動を定電位 下で調べ，対応䊀界では腐食深さが他のランダム粒界に
比べて著しく小さくなることを報告した，さらに粒界腐 食割れでも粒界の方位差依存性があることが見出されて いる. RATH と BERNSTEIN9) は純鉄の水素による粒界割 れが粒界の方位差に 依存することを，さらに著者の 1 人 ${ }^{10)}$ \& $\mathrm{Al}-\mathrm{Cu}$ 合金双結晶の粒界割㣗感受性之粒界特性 （傾角，㸚じれ角）との間に相関性があることを報告し た。

一方，オーステナイト系ステンレス鋼の粒界腐食は主 に粒界の炭化物析出やそれに伴う $\mathrm{Cr}$ 欠乏層の局部腐食 によつて生じるといわれている1112)。また WALKER ${ }^{13)}$ 粒界割䃿々䊉界腐食との関係を $\mathrm{Cr}$ 欠乏層に注目して調 べ，両者が良い対応性を示し，前者では $\mathrm{Cr}$ 欠乏層に塑 性変形が集中することが割れの原因となることを述べて いる. COWAN と GORDON ${ }^{14)}$ は粒界析出物の溶解が割 れ発生の起点として必要であると報告している。ささらに

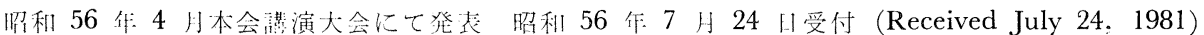

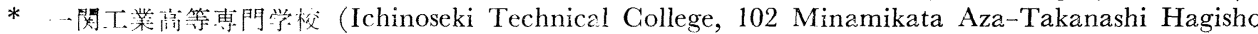
Ichinoseki 021)

*2 一関工業高等専門学校 工博 (Ichinoseki Technical College)

*3 東京大学工学蔀 工博 (Faculty of Engineering, The University of Tokyo) 
粒界析出にも万位差依存性があることが認められてい る.たと壳ば UNWIN と NichOLSON ${ }^{15)}$ 飞よると, Al$\mathrm{Zn}-\mathrm{Mg}$ 合金では粒界析出物の数がランダム粒界で最も 多く，対応粒界では少なく，小傾角粒界では粒界析出物 が添とんど存在しないとしている。 また著者ら ${ }^{8)}$ もイン コネル 600 の時効材で粒界により析出状態が異なり, 析 出のある粒界之ない粒界が存在することを報告した。

しかし，方位差依存性を調べる場合，一般の多結晶体 では，粒界は複雑な形状をしているら党に，共通の回転 軸を持つ粒界の数は乞れ程多くなく, 従つて去の解析に は多大の労力を必要とする，このような困難に対する一 方策として, 本研究では成長方向が $\langle 100\rangle$ 上りなり, 乙 か子直線的な粒界を持っ 304 鋼柱状晶試片を用いて，鋭 敏化材の粒界腐食試験括よび粒界割れ試験を行い，粒界 の方位差依存性を対応粒界に注目して調べ，さらに SPEED 法 ${ }^{16)}$ とより粒界の方位差と析出状態についても 若干の検討を加光た。

\section{2. 実 験 方 法}

用いた試料は連続鋳造材で，その化学成分を Table 1 に示した. 試片は幅 $4 \mathrm{~mm}$, 厚さ $2 \mathrm{~mm}$, 長さ $80 \mathrm{~mm}$ に, 長手方向が粒界に直角になるよう無歪久的に切り出 し, $1373 \mathrm{~K}-3.6 \mathrm{ks}$ 水焼入和の溶体化処理を行い, 923 K-7.2 ks の鋭敏化处理を施したもの（以下単唋敏化 材之呼ぶ）打よび燒入れ 後引張試験機で $3.0 \%$ の歪及 を与光た 後 $823 \mathrm{~K}-7.2 \mathrm{ks}$ の鋭敏化処理を施したもの （以下予昰多後の鋭敏化材と呼ぶ）を用いた·表面はエメ リ紙で研摩後, 表面の加工層を除去するため硫酸一ク口 么酸溶液中で $10 \mathrm{~V}-10 \mathrm{~s}$ の電解研磨を行つた. 柱状晶の 粒径は 2 3 mm であるので, 試片の厚さは泳 1 結晶 粒からなる. Photo. 1 飞試片のマクロ組織を示した・柱 状晶の成長方向路よび粒界の方位差の測定は次の方法に よつた. すなわち $0.5 \mathrm{kmol} / \mathrm{m}^{3}, \quad \mathrm{H}_{2} \mathrm{SO}_{4}+2.5 \mathrm{~mol} / \mathrm{m}^{3}$ ， $\mathrm{NH}_{4} \mathrm{SCN}$ 溶液中, $-0.16 \mathrm{~V}$ (vs. SCE) で $1.8 \mathrm{ks}$ エッ チングすることにより $\{111\}$ facet（溶故残り面）で囲亦

Table 1. Chemical composition of specimen (mass $\%)$.

\begin{tabular}{|c|c|c|c|c|c|c|c|c|}
\hline & G & $\mathrm{Si}$ & $\mathrm{Mn}$ & $P$ & $\mathrm{~S}$ & $\mathrm{Ni}$ & $\mathrm{Cr}$ & $\mathrm{N}$ \\
\hline 304 & 0.060 & 0.54 & 1.34 & 0.026 & 0.010 & 8.72 & 18.19 & 0.016 \\
\hline
\end{tabular}

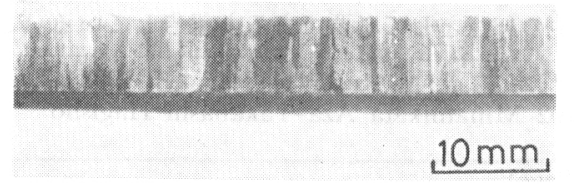

Photo. 1. Macrostructure of columnar crystals.
れた $40 \sim 50 \mu$ 程度の方位ピットを作成し, 構成面の角 度を傾角顕微鏡で測定することにより決定した。

粒界腐食試験 ${ }^{17}$ ) は Strauss 試験法（沸騰硫酸一硫酸銅 溶液）および沸騰 $10 \mathrm{kmol} / \mathrm{m}^{3}, \mathrm{HNO}_{3}$ 溶液中に $2.6 \times$ $10^{5} \mathrm{~s}$ 自然浸漬する方法をとつた，粒界割れ試験条件は， $\mathrm{FeCl}_{3}$ 溶液中で割れが起こること息索考として, 室温 の $0.26 \mathrm{kmol} / \mathrm{m}^{3}, \mathrm{FeCl}_{3}$ 溶液中で $200 \mathrm{MPa}$ (降伏応力 $180 \mathrm{MPa}$ ) の応力を負荷しつつ $3.46 \times 10^{5} \mathrm{~s}$ 自然浸漬す る方法をとつた。 さらに一部， 3 点支持曲げ試験も併用 した．粒界腐食深さ㧍よび粒界割れ深さは断面を光学䫓 微鏡で観察し，接眼ミクロメータで測定した。

粒界析出の観察は非水溶媒系電解溶液中で定電位ェッ チングする方法 (SPEED 法) 16)を採用した. すなわか 10\%アセチルアセトン - 1\% テトラメチルアンモニウム クロライドーィチルアルコール溶液中, $+0.5 \mathrm{~V}$ (vs. SCE) でェッチングし，粒界を走查電顕で観察した。 また粒界 の方位差はとのとき生成する方位ピットの向きから測定 した. $3 \cdot 1$ で後述するよらに単純傾角粒界とみなしらる ために，ステレオ投影を経ずに多数の粒界傾角を測定し らることは本試片の最大の利点である.

\section{3. 実 験 結 果}

\section{1 柱状晶の成長方向}

立方晶金属の融液からの凝固成長方向は〈100〉で㐫

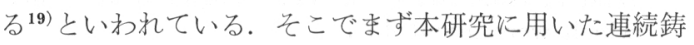
造材の柱状晶の成長方向をそれに 直角な断面で測定し た。矢の結果, Fig. 1 亿示す上らに成長方向は〈100〉 から $10^{\circ}$ 以内の範囲にあることがわかつた。このことは 粒界は添潘〈100〉回転軸を持つ単純傾角粒界として取り 扱らことができることを示している，次に回転角 $(\omega)$ が 0 ～45 の範囲で種々の解度を持つ粒界がどの程度存 在するかを 100 個の粒界について 50間隔で調べた。 そ

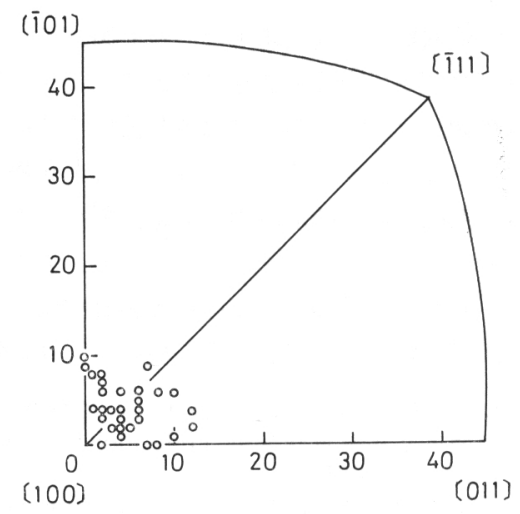

Fig. 1. Growth direction of columnar crystals. 
の結果を Fig. 2 に示した. 多少のばらつきはあるが, $0 \sim 45^{\circ}$ までの種々の $\omega$ を持つ粒界が均等に存在する・こ のことは本試片が $\omega$ の影響を系統的に調べるのに適して いることを示している.

\section{$3 \cdot 2$ 粒界腐食試験}

前述したように，粒界はく100〉回転軸を持つ単純傾角 粒界として取り扱え，また粒界はある特定の $\omega$ の值で対 応粒界になることが知られている ${ }^{20)}$ 。このらち 17 および $\Sigma 5$ ( 2 は対応粒界を示し, 数字はその対応性 を示す.) の対応粒界に注目しながら，粒界腐食深さ

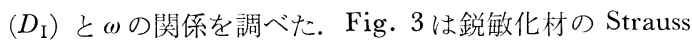
試験における $D_{\mathrm{I}}$ と $\omega$ の関係を示したものである． $D_{\mathrm{I}}$ は $\omega$ の増加とともに大きくなるが， $\Sigma 13 ， \Sigma 17$ および $\Sigma 5$ の対応粒界付近で明らかに減少与る。またいが $40^{\circ}$ 以上 でも $D_{\mathrm{I}}$ は小さい. Fig. 4 に鋭敏化材の沸騰 $10 \mathrm{kmol} /$ $\mathrm{m}^{3}, \mathrm{HNO}_{3}$ 溶液中での $D_{\mathrm{I}}$ と $\omega$ の関係を示した. Strauss 試験と同様に $\Sigma 13 ， \Sigma 17$ および $\Sigma 5$ の対応棹界付近で明 らかに $D_{\mathrm{I}}$ の減少が垫められる。一力, 溶体化処理後, 予

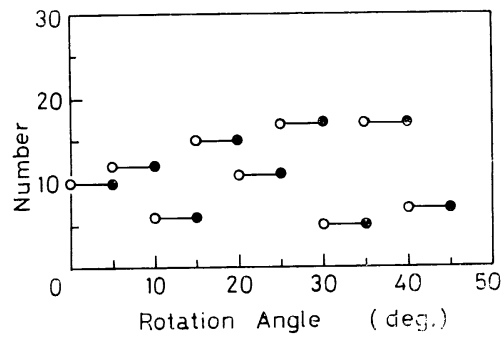

Fig. 2. Number of grain boundaries with various rotation angles about $\langle 100\rangle$ axis.

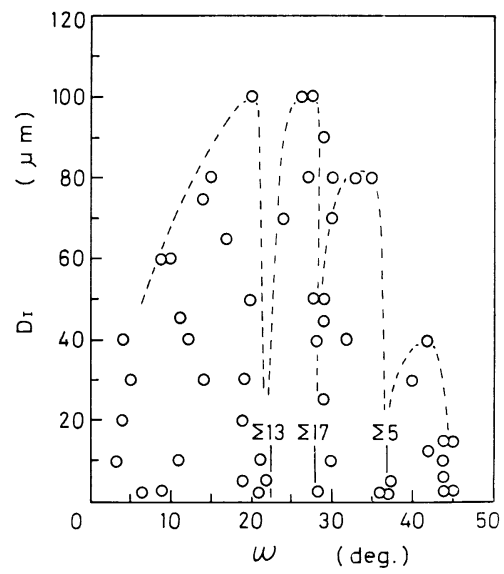

Fig. 3. Relation between the depth of intergranular corrosion $\left(D_{\mathrm{I}}\right)$ tested with Strauss method and rotation angle $(\omega)$ about $\langle 100\rangle$ axis of the specimens water-quenched, followed by sensitization at $923 \mathrm{~K}$ for $7.2 \mathrm{ks}$.
歪みを与えると鋭敏化温度が低温側に移動する21)ことが 知られているので, 予歪及後の鋭敏化材についても $D_{\mathrm{I}}$ とのの関係を Strauss 試験で調べた. その結果を Fig. 5 に示した. Fig. 3 および Fig. 4 と同様に対応粒界 付近と $\omega$ が $40^{\circ}$ 以上で $D_{\mathrm{I}}$ の減少が認められる. しかし $\omega$ が $10^{\circ}$ 以下では $D_{\mathrm{I}}$ の大きい粒界と小さい粒界が存在 するが，その理由については後述する.

\section{3 粒界割れ試験}

$0.26 \mathrm{kmol} / \mathrm{m}^{3}, \mathrm{FeCl}_{3}$ 溶液中, $200 \mathrm{MPa}$ の応力で 単 軸引張りによる粒界割れ試験を行つた。 Fig. 6 は鋭敏 化忉の粒界割れ深さ $\left(D_{\mathrm{C}}\right)$ と $\omega$ の関係を, Fig. 7 は予

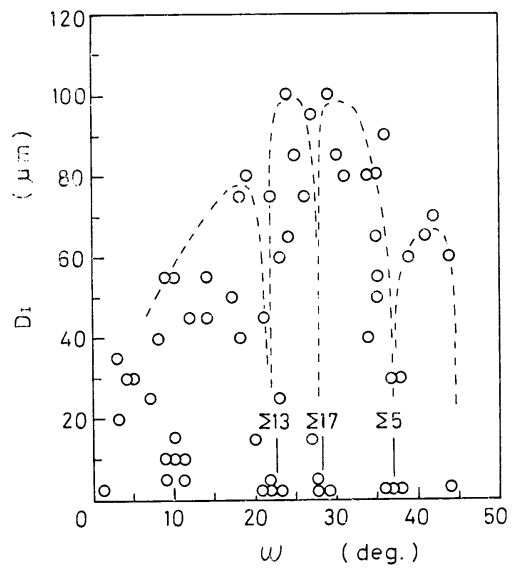

Fig. 4. Relation between the depth of intergranular corrosion $\left(D_{\mathrm{I}}\right)$ tested in boiling $10 \mathrm{kmol} / \mathrm{m}^{3}-\mathrm{HNO}_{3}$ solution and rotation angle $(\omega)$ about $\langle 100\rangle$ axis of the specimens water-quenched, followed by sensitization at $923 \mathrm{~K}$ for $7.2 \mathrm{ks}$.

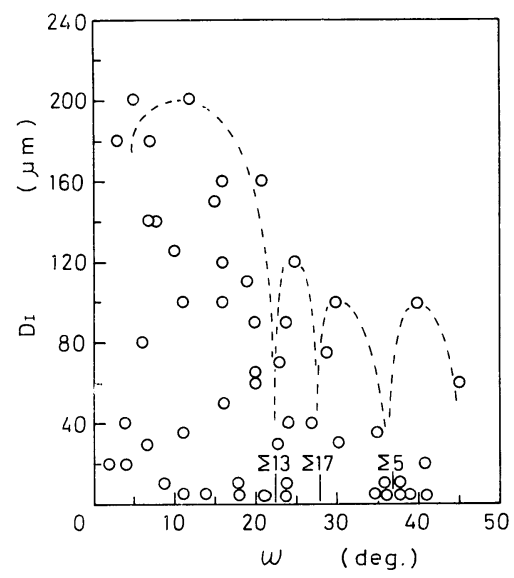

Fig. 5. Relation between the depth of intergranular corrosion $\left(D_{\mathrm{I}}\right)$ tested with Strauss method and rotation angle $(\omega)$ about $\langle 100\rangle$ axis of the specimens water-quenched, followed by sensitization at $823 \mathrm{~K}$ for $7.2 \mathrm{ks}$ after strained to $3.0 \%$. 


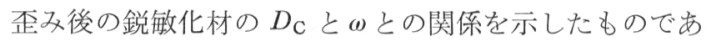
る. いずれる $\Sigma 13 ， \Sigma 17$ 㶦よび $\Sigma 5$ の対応粒界付近と $\omega か ゙ 40^{\circ}$ 以上で $D_{\mathrm{C}}$ の減少が認められる。 本たFig. 7亿 拈いても Fig. 5 と同様に $\omega$ が $10^{\circ}$ 以下で $D_{\mathrm{C}}$ の大きい 粒界と小さい粒界が存在する。

\section{4. 考察}

前述したように, $D_{\mathrm{I}}$ 抢よび $D_{\mathrm{C}}$ はいずれの試験条件

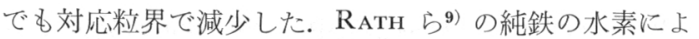
る粒界割れ試験結果によると，割れが生じない粒界は

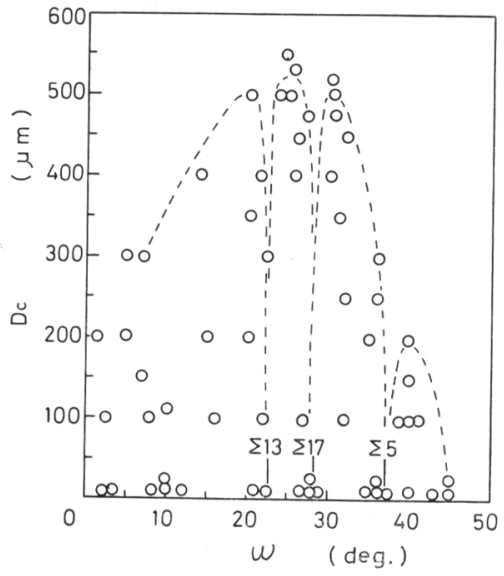

Fig. 6. Relation between the depth of intergranular stress corrosion cracking $\left(D_{\mathrm{C}}\right)$ tested in $0.26 \mathrm{kmol} /$ $\mathrm{m}^{3}-\mathrm{FeCl}_{3}$ solution and rotation angle $(\omega)$ about $\langle 100\rangle$ axis of the specimens water-quenched, followed by sensitization at $923 \mathrm{~K}$ for $7.2 \mathrm{ks}$. $\langle 110\rangle$ 回転軸で $10^{\circ}$ 以下々 $27^{\circ}$ 付近拈よび $40^{\circ}$ 付近飞亦 り，それぞれ $\Sigma 19$ 抢よび $\Sigma 9$ の対応粒界に相当してい る.さらに $\langle 100\rangle$ 回転軸でも $10^{\circ}$ 以下と $28^{\circ}$ 付近の $\Sigma 17$ の対応粒界に相当して拉り，本研究の粒界腐食拈よび粒 界割れ試験結果とよい対応性を示している。 Photo. 2

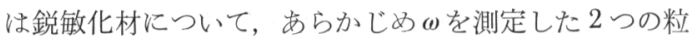
界, 寸なわち $\omega=23^{\circ}, \Sigma 13$ の対応粒界 (G. B-I) と $\omega=8^{\circ}, \quad$ ランダム䊉界 $(\mathrm{G} . \mathrm{B}-\mathrm{II})$ のみを露出して 3 点 支持曲げ試験を行つた後の試片表面を示したものであ

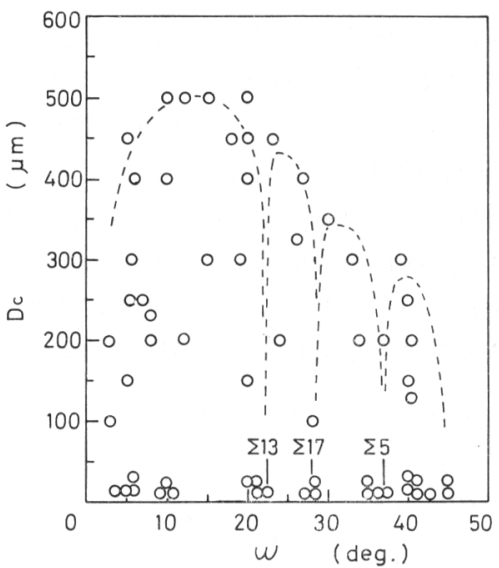

Fig. 7. Relation between the depth of intergranular stress corrosion cracking $\left(D_{\mathrm{C}}\right)$ tested in 0.26 $\mathrm{kmol} / \mathrm{m}^{3}-\mathrm{FeCl}_{3}$ solution and rotation angle $(\omega)$ about $\langle 100\rangle$ axis of the specimens waterquenched, followed by sensitization at $823 \mathrm{~K}$ for $7.2 \mathrm{ks}$ after strained to $3.0 \%$.
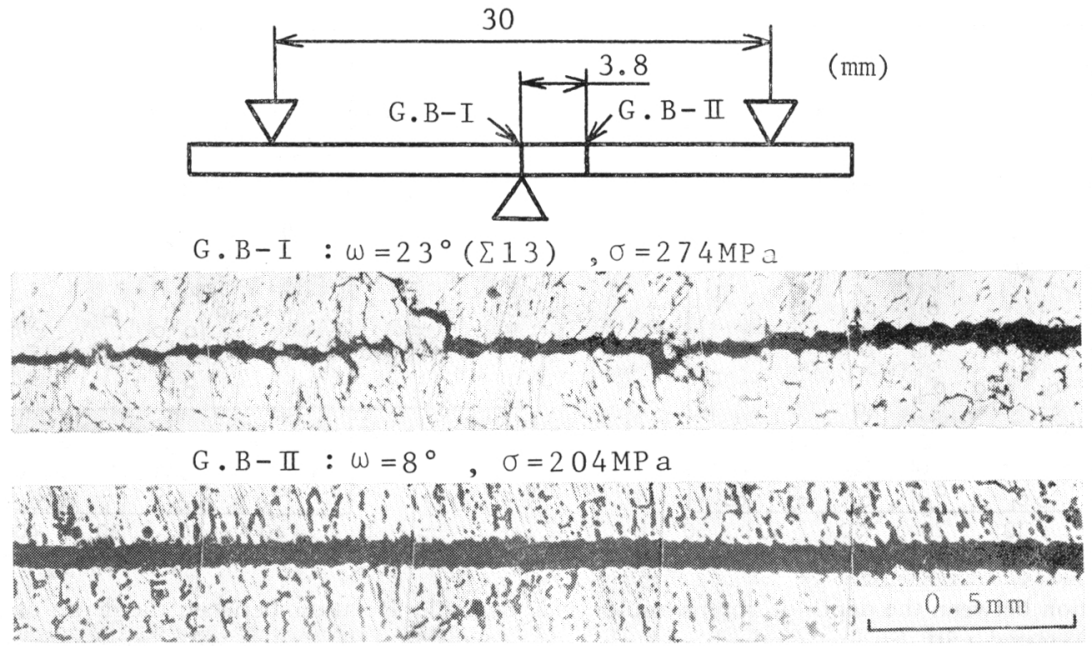

Photo. 2. Microstructure of the cracked surface of the specimen water-quenched, followed by sensitization at $923 \mathrm{~K}$ for $7.2 \mathrm{ks}$ and tested with three points bending method in $0.26 \mathrm{kmol} / \mathrm{m}^{3}-$ $\mathrm{FeCl}_{3}$ solution. 
る、中心部にある G. B- I より $3.8 \mathrm{~mm}$ 離れた応力 の低い G. B-II で顕著な割れが観察され，D居 G.BII の方が G. B-I より深い。さらに表面には鋳造材

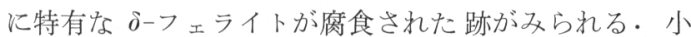
若ら ${ }^{22}$ は $\delta$-フェイト中の $\mathrm{Cr}$ 含有量がオーステナイ ト中のそれよりも高いにもかかわらず, $\mathrm{MgCl}_{2}$ 溶液中 では $\delta$ エライトの方が腐食されやすいと述べている が，本研究では後述するように $\omega$ による粒界上の $\delta$-フ ェライトの量の差はそれ程認められないので, 割れ感受 性はむしろ心に依存すると考党られる。

一方，予歪文後の鋭敏化材の $\omega<10^{\circ}$ の粒界では $D_{\mathrm{I}}$ および $D_{\mathrm{C}}$ の大きい粒界之小さい粒界が存在した。 その 原因としては予歪みを与光たときの隣接粒の变形の難易 がその後の鋭敏化に伴う粒界近傍への析出状態に大きな 影響を与えることによるものと考えられる・そこで Fig. 5 の $\omega<10^{\circ}$ の粒界について隣接粒の引張軸方位（ステ レオ投影図の〈100 から〈110 の大円上にあり，その最 大角は $45^{\circ}$ である.) と $D_{\text {I }}$ および Schmid 因子との関 係を調ベた。その結果をFig. 8 に示した。同図（a で Schmid 因子は引張方位が〈100〉と〈110〉から離れ るにつれて大きくなり，中間付近で最大となる。同図 (b)の互いに円弧で結んである 2 点の角度差が $\omega$ に相当 する. $\omega<10^{\circ}$ では隣接粒の Schmid 因子が大きい粒 界では $D_{\mathrm{I}}$ は深く，逆に Schmid 因子が小さい粒界で

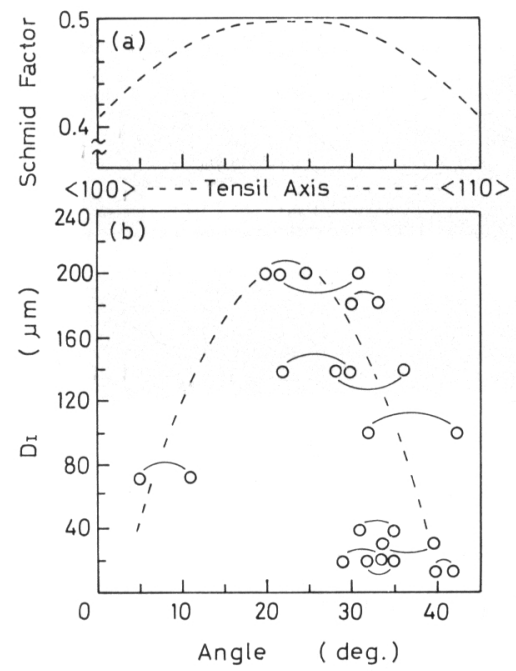

Fig. 8. (a) Relation between Schmid factor and tensil axis and (b) relation between the depth of intergranular corrosion $\left(D_{\mathrm{I}}\right)$ and tensil axis of component crystals of the grain boundaries with $\omega$, which were less than $10^{\circ}$ in Fig. 5. Difference in degree between the points connected by the solid line corresponds with $\omega$.
は $D_{\mathrm{I}}$ は浅い。すなわち予歪及を与えた $\omega<10^{\circ}$ の粒界 腐食は $\omega$ の大きさと同時に粒界近傍の隣接粒の塑性変形 の難易も重要であることを示唆している，それに対して $\omega>10^{\circ}$ の粒界では Fig. 5 に示したように対応粒界で $D_{\mathrm{I}}$ が減少していることから，この場合には $\omega$ の值のみ が重要で，隣接粒のSchmid 因子の大ささはとれ程影響 しないと考光られる。このような傾向は粒界割れにおけ

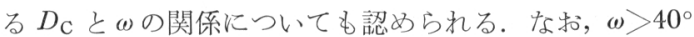
では試験条件のいかんにかかわらず $D_{\mathrm{I}}, D_{\mathrm{C}}$ ともに小 さくなるが，この理由については目下のところ不明であ る.

Photo. 3 は予歪久後の鋭敏化材の粒界割れ破面を示 したもので，すべり線と一部に $\delta$ ーフェライトが溶出し

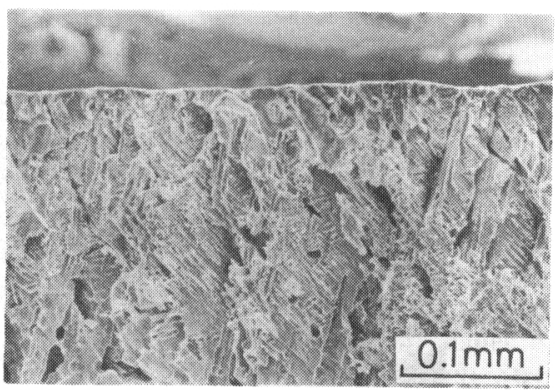

Photo. 3. Fractgraph of intergranular stress corrosion cracking of the specimen water-quenched, followed by sensitization at $823 \mathrm{~K}$ for $7.2 \mathrm{ks}$ after strained to $3.0 \%$.

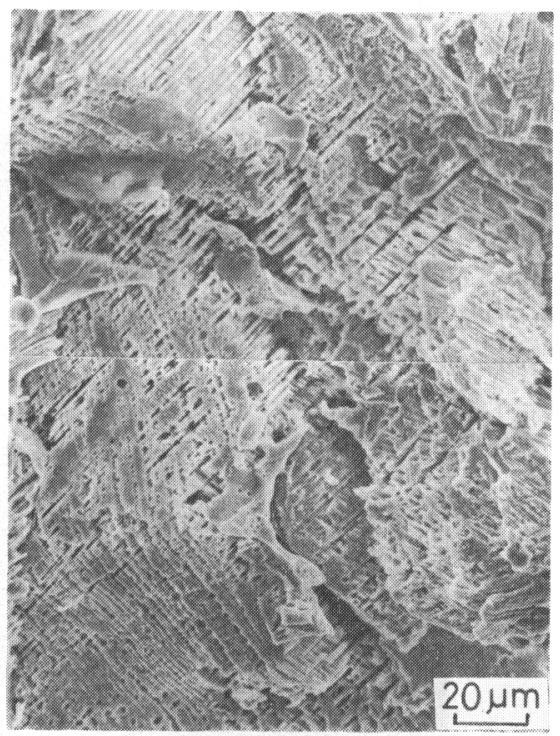

Photo. 4. Preferential attack along slip lines on the fractured surface of the specimen water-quenched, followed by sensitization at $823 \mathrm{~K}$ for $7.2 \mathrm{ks}$ after strained to $3.0 \%$. 
た跡がみられる。このような様相は予歪みを与完ない場 合にも認められるが，予歪みを与充たものでは Photo. 4 に示すようにすべり線に沿つた顕著な腐食溝が存在す る.このことからも変形がその後の鋭敏化に伴ら粒界へ の析出状態, ひいては粒界腐食や粒界割れに影響するこ とが予想される．本研究に用いている鋳造材では $\delta$-フ ェライトは粒内, 粒界ともに存在し, $1373 \mathrm{~K}-360 \mathrm{ks}$ 以 内の溶体化処理ではその量はそれ程減少しない。一方, 種々の心を持つ粒界破面上での溶出跡から $\delta$-フェライ トの量や分布を調べると， ない。従つて，粒界执よびその近傍に存在する $\delta$-フェ ライトは, $\omega$ の值とは独立に, 同程度に $D_{\mathrm{I}}$ や $D_{\mathrm{C}}$ に影 響を与えていると考学られる。
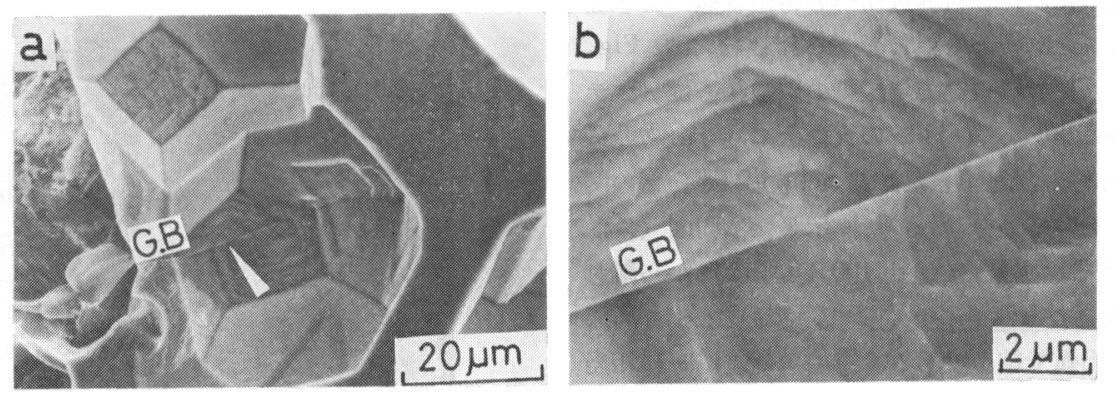

Photo. 5. Microstructures of the specimen water-quenched, followed by sensitization at $923 \mathrm{~K}$ for $7.2 \mathrm{ks}$ : (a) shows oriented pits and grain boundary (G. B), (b) shows G. B free from carbide. This G. B corresponds to coincidence boundary of $\Sigma 13$.
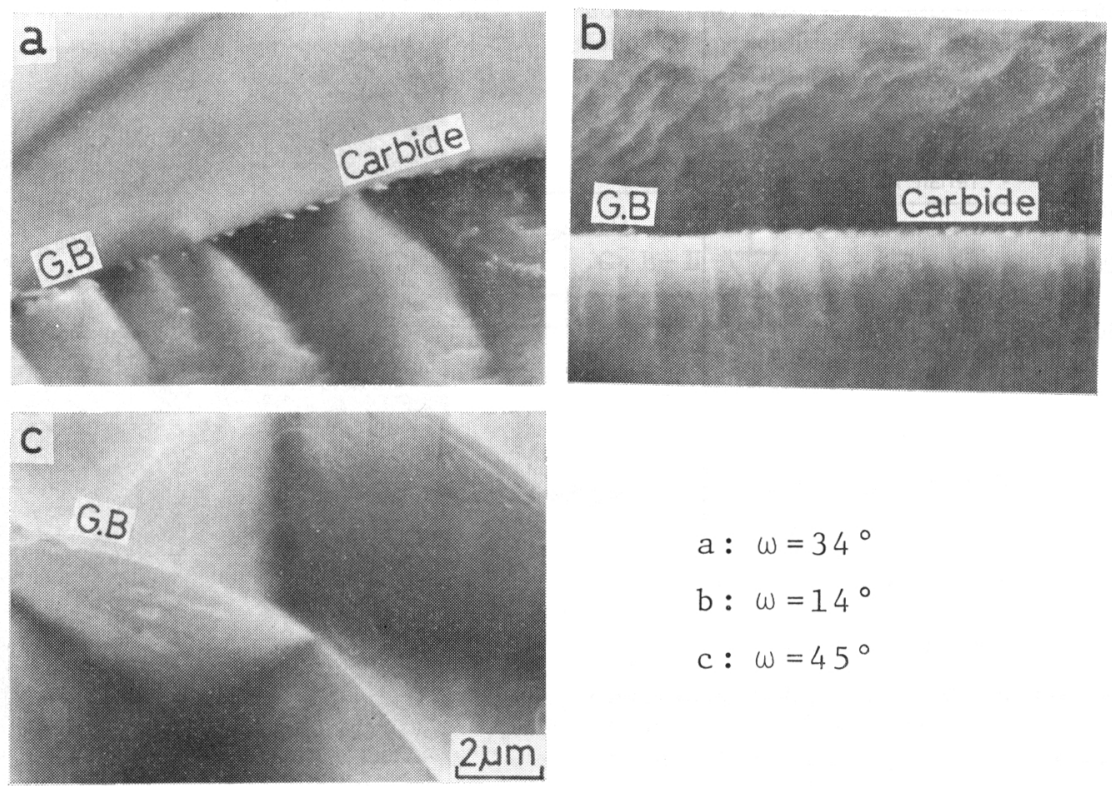

$$
\begin{aligned}
& \text { a: } \omega=34^{\circ} \\
& \text { b: } \omega=14^{\circ} \\
& \text { c: } \omega=45^{\circ}
\end{aligned}
$$

Photo. 6. Microstructures of the specimen water-quenched, followed by sensitization at $923 \mathrm{~K}$ for $7.2 \mathrm{ks}$ : (a) and (b) show grain boundaries (G. B) with carbide, and (c) shows G. B free from carbide. 
ダム粒界で同様に炭化物が観察される。これらの炭化物 は従来の報告 ${ }^{11) 21)}$ から $\mathrm{M}_{23} \mathrm{C}_{6}$ に相当すると思われる. しかし, 同 (c)の $\omega=45^{\circ}$ のランダム粒界では炭化物は 認められない。このように炭化物が認められない粒界は Figs. 3〜7に示したよらに䊉界腐食および粒界割机感受 性の小さい粒界であることがわかる.

\section{4. 結}

\section{論}

〈100〉回転軸を持つ 304 鋼柱状晶試片の鋭敏化材につ いて粒界腐食試験および粒界割れ試験を行い，粒界腐食 深さ $\left(D_{\mathrm{I}}\right)$ および粒界割れ深さ $\left(D_{\mathrm{C}}\right)$ と回転角 $(\omega)$ と の関係を対応粒界に注目して調べ，さらに粒界への炭化 物析出と方位差との関係についても検討した結果, 次の 結論を得た。

（1） $923 \mathrm{~K}-7.2 \mathrm{ks}$ の鋭敏化処理を施した試料の Strauss 試験拈よび沸騰 $10 \mathrm{kmol} / \mathrm{m}^{3}, \quad \mathrm{HNO}_{3}$ 試験に抒 いて， $D_{\mathrm{I}}$ は $\omega$ に依存し対応粒界付近および $\omega<10^{\circ}$ と $\omega>40^{\circ}$ の粒界で減少した。

(2) $3.0 \%$ の予雪父後, $823 \mathrm{~K}-7.2 \mathrm{ks}$ の鋭敏化処理 を施した試料の Strauss 試験において， $D_{\mathrm{I}}$ は対応粒界 付近および $\omega>40^{\circ}$ の粘界で咸少した. $\omega<10^{\circ}$ では $D_{\mathrm{I}}$ の大きい粒界と小さい粒界とがあり，前者では Schmid 因子が大きく, 後者では小さい. このことは $D_{\mathrm{I}}$ が単に のだけでなく精界近傍の塑性変形の難易にもよることを 示唆している.

(3) $923 \mathrm{~K}-7.2 \mathrm{ks}$ の鋭敏化打よび $3.0 \%$ の予歪文 後, $823 \mathrm{~K}-7.2 \mathrm{ks}$ の鋭敏化处理を施した試料の 0.26 $\mathrm{kmol} / \mathrm{m}^{3}, \mathrm{FeCl}_{3}$ 溶液中での $D_{\mathrm{C}}$ はいずれも対応粒界付 近および $\omega>40^{\circ}$ の粒界で減少した。 また後者の試料の $\omega<10^{\circ}$ の粒界では $D_{\mathrm{C}}$ が大きい粒界と小さい粒界があ り， $D_{\mathrm{I}}$ と同様，前者では Schmid 因子が大きく，後者 では小さい.

（4）粒界への炭化物析出は方位差に依存し，炭化物 はランダム粒界で認められるが，対応粒界や $\omega=45^{\circ}$ の 粒界では認められない。また炭化物の認められない粒界 と粒界腐食および粒界割れ感受性の小さい粒界とが良く 対応する。

単純傾角粒界をもつ粗大柱状晶試片を用いる方法は粒 界構造の効果を能率的に調べうる有力な手段のひとつで
あると思われる。

\section{交献}

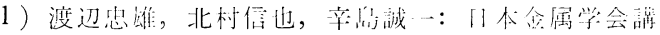
演卢留集，(1978 作１１～月），p. 99

2 ) $T$. Watanabe, $T$. Murakami, and $S$. Karashima: Script. Met., 12 (1978), p. 361

3 ) $M$. Biscondi and $C$. Goux: Mem. Sci. Rev. Met. 65 (1968), p. 167

4 ) $T$. Watanabe, $M$. Yamada, $S$. Shima, and S.Karashima: Phil. Mag., 40 (1979), p. 665

5 ) J. Y. Boos and C. Goux: Proc. U. R. Evans: Inter. Conf. on Localized Corrosion, NACE, (1971), p. 556

$6)$ O. $P$. Arora and $M \cdot$ Metzger: Trans. Met. Soc. AIME, 236 (1966), p. 1205

7 ) M. Froment: J. de Physique, 36 (1975), C4 $4-371$

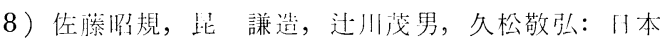
金属学会流, 43 (1979), p. 664

9 ) B. B. Rath and $I$. M. Bernstein: Met. Trans., 2 (1971), p. 2845

10）昆謙造，大谷南海贸：日本金属学会誌，37 (1973)，p. 289

11）久松敬引，小川洋之：鉄之鋼，63 (1977), p. 585

12）邀沢治一郎：防食技術，22（1973)，p. 267

13) W. L. Walker: Corrosion, 74, Paper No. 53

14) R. L. Cowan and G. M. Gordon: Stress Corrosion Cracking and Hydrogen Embrittlement of Iron Base Alloys, NACE-5 (1973), p. 1023

15) D. N.T. Unwin and R. B. Nigholson: Acta Met. 17 (1969), p. 1363

16)照澤交夫，田口勇，松本龍太郎：日本金属学会 誌，43 (1979) p. 1068

17）椙山正孝：ステンレス鋼腐食試験方法の現状， (1968)，p. 44，81，ステンレス協会

18) $R . M$. Latanision and $R$. $W$. Staehle: Fundmental Aspect of Stress Corrosion Cracking, (1976), p. 214 [The Ohio State University]

19) G. Wasserman and $J$. Grewen: Texture metallischer Werkstoffe (1962), p. 122

20) D. G. Brandon, B. Ralph, $S$. Ranganathon, and $M . S$. WALD: Acta Met. 12 (1964), p. 813

21）近崎充夫，添野 浩：鉄と鋼，64 (1978), p. 1363

22) 小汻正倫, 工藤越夫：腐食防食協会講演予稿集, (1978 年 5 月), p. 243 